\title{
Margaret McCartney: The ethics of behavioural incentives
}

\author{
Margaret McCartney general practitioner, Glasgow
}

Sticks and carrots; push and pull. Research has shown that providing $£ 400$ worth of shopping voucher incentives raised the chances of pregnant women stopping smoking from $8.6 \%$ to $22.5 \% .{ }^{1}$ Some low quality evidence has found that financial incentives to breast feed can increase its prevalence, and further research is ongoing..$^{3}$ And cash rewards reduce smoking rates, but few trials have reported success after the close of the programme. $^{4}$

The National Institute for Health and Care Excellence (NICE) recommends "contingency management" programmes, which award vouchers to people treated for addiction if they test negative for illicit drugs. NICE suggests providing "shopping vouchers of up to $£ 10$ in value" for completing HIV testing and hepatitis immunisation. ${ }^{5}$

But should the relationship between professionals, patients, carers, and families become one of financial incentives? Should doctors offer not just evidence about why a particular behaviour is better but also money in an envelope? It seems ethically dubious to offer cash incentives that can be withheld for "failure to comply"- but this approach sometimes works better than standard care. It may help people from the most deprived communities, who already carry the greatest burden of inequality. The research is brave, even if controversial.

Are there other ways of getting the same effect? Gambling your own money against a National Incentives Service bookkeeper might be a more ethical way to make the best use of incentives: the competition would be against oneself, a contract administered separately from health professionals. Some trials to quit smoking have used a "deposit refund" strategy with as much or more success when compared with rewards, but they generally have poorer take-up. US "social gaming" websites already offer such a service, ${ }^{6}$ where people are more likely to lose more weight with the more they bet on it. However, one randomised controlled trial has shown short term benefit over months, ${ }^{7}$ when we really need interventions that work over years.

It's not only patients who have been offered incentives but also GPs, through the Quality and Outcomes Framework. "Points for prizes" turns out to be morale sapping, shameful work, and finding the right boxes to tick occupies time that should be spent listening to patients. These incentives have changed the nature of the consultation, and most patients don't know the ugly truth of how we are paid.

The jury is still out on incentives for behavioural change. My unease stems from the fact that $£ 10$, not a lot of money, is enough to persuade people to have a vaccination or take a blood test. Does this mean that incentives work only because of inequality-because people are poor?

Competing interests: I have read and understood the BMJ policy on declaration of interests and declare the following interests: I'm an NHS GP partner, with income partly dependent on Quality and Outcomes Framework points. I'm a part time undergraduate tutor at the University of Glasgow. I've written two books and earn from broadcast and written freelance journalism. I'm an unpaid patron of Healthwatch. I make a monthly donation to Keep Our NHS Public. I'm a member of Medact. I'm occasionally paid for time, travel, and accommodation to give talks or have locum fees paid to allow me to give talks but never for any drug or public relations company. I was elected to the national council of the Royal College of General Practitioners in 2013 and am chair of its standing group on overdiagnosis. I have invested a small amount of money in a social enterprise, Who Made Your Pants?

Provenance and peer review: Commissioned; not externally peer reviewed.

Follow Margaret on Twitter, @mgtmccartney

1 Tappin D, Bauld L, Purves D, et al. Financial incentives for smoking cessation in pregnancy: randomised controlled trial. BMJ 2015:350:h134.

2 Bassani DG, Arora P, Wazny K, Gaffey MF, Lenters L. Financial incentives and coverage of child health interventions: a systematic review and meta-analysis. BMC Public Health 2013;13 (suppl 3):S30.

3 Relton C, Whelan B, Strong M, et al. Are financial incentives for breastfeeding feasible in the UK? A mixed methods field study. Lancet 2014;384:S5.

4 Cahill K, Hartmann-Boyce, Perera R. Incentives for smoking cessation. Cochrane Database Syst Rev 2015;5:CD004307.

5 National Institute for Health and Care Excellence. Drug misuse-psychosocial interventions. July 2007. www.nice.org.uk/guidance/cg51/resources/guidance-drug-misusepsychosocial-interventions-pdf.

6 Leahey T, Rosen J. DietBet: a web based program that uses social gaming and financial incentives to promote weight loss. JMIR Serious Games 2014:2:e2.

7 Volpp KG, John LK, Troxel AB, Norton L, Fassbender J, Loewenstein G. Financial incentive based approaches for weight loss. JAMA 2008;300:2631-7. 
